\title{
Bold and Newly Independent, or Isolated and Cast Adrift? The Implications of Brexit for Intellectual Property Law and Policy ${ }^{*}$
}

\author{
BENJAMIN FARRAND \\ University of Warwick
}

\begin{abstract}
What happens when a breakdown in relations results in mutually possessed objectives becoming harder to achieve? This article explores the consequences of the UK's withdrawal from the EU for intellectual property (IP) law and policy. Compared with other fields such as Economic and Monetary Union and the development of the EU's 'social chapter', the UK has been a supportive and proactive player in internal market integration, particularly pertaining to IP protection. As a result of 'Brexit', the EU may find that the impetus for further harmonization and integration in this field is lost, such as with the EU unitary patent. However, the consequences for the UK are likely to be more severe - a loss of influence, both over laws that govern it and in exporting IP norms internationally, as well as a loss of access to certain protections, agencies and market sectors that are within the UK's economic interests.
\end{abstract}

Keywords: Market integration; intellectual property; Brexit; European Economic Area; international trade

\section{Introduction}

The vote by the British public to leave the EU, considered as a remote possibility by polling companies and financial markets alike, has nevertheless left the EU and UK in a position of significant uncertainty. Whether decided on the basis of fears over immigration (or, as some may argue, outright xenophobia) and 'euro-myths' peddled by unscrupulous UK journalists

\footnotetext{
${ }^{*}$ The author would like to sincerely thank the referees for their helpful comments and suggestions for revision of this article.
} 
and politicians (Craig, 2016, p. 455), or concerns over the economy, sovereignty and Britain's place in the world, the vote has implications for the future of the United Kingdom with a renewed impetus for Scottish independence, questions over the status of Northern Ireland, and of course, Gibraltar. Further uncertainty surrounds the resignation of David Cameron and subsequent appointment of Theresa May as British Prime Minister, the appointment of Boris Johnson as Foreign Minister and David Davis as Secretary of State for Exiting the EU, and the somewhat parodied 'Brexit means Brexit' statement of the Prime Minister on behalf of the British Government. Uncertain too is when negotiations will begin, with reports of the March 2017 invocation of Article 50 of the Lisbon Treaty, which constitutes the 'starting gun' for withdrawal negotiations, potentially being subject to delay. And what, to throw something of a wild card into this already somewhat unstable looking house of cards, are the implications of the recent decisions and actions on international trade by newly elected President Trump? We live, as the Chinese proverb states, in interesting times.

The purpose of this article is to consider the potential implications of the withdrawal of the UK from the EU for a specific area of public policy, namely intellectual property (hereafter IP) law and intellectual property rights (IPRs), guided by the question 'what are the implications of UK withdrawal from the EU for IP law and policy?' A number of alternatives to full membership have been proposed, from membership of the European Economic Area (EEA) similar to that of Norway, Iceland and Liechtenstein, to a series of bilateral agreements akin to those made with Switzerland, or even going it alone under World Trade Organization (WTO) rules. As this article will demonstrate, however, under all these options, the implications for IP-intensive sectors in the UK are negative, ranging from a loss of influence over laws that may nevertheless bind it if it wishes to trade with the EU, a loss of ability to influence IP norms in its favour through international agreements, and a loss of access to specific protections, agencies and market sectors in the EU. This article presents a new contribution to the analysis of the implications of Brexit, in a field given comparatively little attention when compared to issues such as financial regulation, services and passporting ${ }^{1}$ in which firms based outside of the EU can set up a subsidiary in the UK and thereby gain access to capital

\footnotetext{
1 This article does not expand upon the issue of financial services regulation and the Brexit implications as it is largely outwith the main expertise of the author, but has been considered in works by authors such as Mugarura (2016) and Yeoh (2016).
} 
markets in the entire Union (for more on passporting, see McCreevy, 2006; see also Black, 2002). However, by focusing on IPR protection, another dimension of the difficulties the UK is likely to experience can be further understood.

The EU, along with countries such as the US and Japan, have been the forefront historically of developing laws pertaining to the protection of IP assets, be they Hollywood movies, pharmaceutical products or brand identities such as McDonalds or Apple. Loosely categorized as a form of 'property', IP is ultimately about the protection of intangible, knowledge-based assets. While this undoubtedly causes some debate in the legal literature that will not be repeated here, for the purposes of this article, it seems sufficient to define IP law as a regulatory system seeking to afford quasi-property rights to knowledge-based assets, so as to derive economic benefit from them (for more on the idea of IP as regulation, see Patterson, 1986). The three main forms of IP can be categorized as copyright, which protects creative expression such as film, literature and music; patent, which protects inventions or innovations, such as pharmaceuticals, and trade mark, which protects the brands, logos and by extension trading reputation of undertakings. IPRs are considered as a valuable business asset, as well as of fundamental importance to the economy more generally (see for example Hall, 2009; Posner, 2005). According to the UK's Intellectual Property Office (IPO), the governmental agency responsible for managing the registers for IP rights such as patents and trade marks, in 2011 the value of IP assets protected by IPRs in the UK constituted $£ 63.5$ billion, equivalent to 4.2 per cent of the UK's Gross Domestic Product (GDP) (Intellectual Property Office, 2015, p. 3). In the EU, a report jointly written by the European Patent Office and European Union Intellectual Property Office (EUIPO, previously the Office for the Harmonization of the Internal Market, or OHIM) states that IPR-intensive industries contribute 26 per cent of employment and 39 per cent of GDP in the EU (European Patent Office and European Union Intellectual Property Office, 2013, p. 6), with considerable trade between the UK and the rest of the EU in IP protected assets. As such, the European Commission has argued, these IPR-intensive sectors are a key asset to the EU (European Commission, 2011a, pp. 4-5), not only as a general guarantor of continued investment in knowledge and innovation to the benefit of European society (European Commission, 2010a, pp. 11-12), but as a specific policy lever for addressing weaknesses in the European economy in light of the eurozone crisis (European Commission, 2011b, pp. 8-9; European Commission, 2011a, p. 3). It is for this reason that the Commission concluded in 2011 that the completion 
of a 'single market' for IPRs was essential to ensuring economic growth, job creation and the EU's continued competitiveness (European Commission, 2011a, p. 6). For these reasons, the harmonization and integration of IP laws in the EU has constituted an important dimension of the EU's internal market policies and law-making, with the UK playing an active part in this process.

This article adopts a predominantly legal analysis of the implications of leaving the EU for the UK's IP regime, bringing in consideration of Europeanization and the EU's trade relations in order to better assess the UK's ability to influence IP norms in the future. The article begins by considering the immediate legal implications for the UK of leaving the EU, including the loss of access to specialized legal regimes for the protection of trade marks and patents, as well as the potential loss of access to the digital single market for works protected by copyright. In the subsequent section, it considers just how 'independent' the UK's IP laws may be after Brexit, considering the implications of laws and norms continuing to bind the UK in the event of joining the EEA, forming bilateral agreements, or acting solely under WTO rules, in order to demonstrate that even absent EU membership, its IP laws may still continue to have effect in the UK. In the final section, this article will demonstrate that while the EU exercises considerable trade power, and indeed power through trade, the UK does not share the same privilege as a single state - this will have significant implications for negotiations with the EU, as well as the renegotiation of protections with states where, by virtue of having left the EU and by extension the trade agreements the EU is party to, the UK is no longer protected on the same terms.

\section{Changing Relationships with the EU: the Substantive Implications of Brexit for IP Law}

By leaving the EU, regardless of the form that this separation takes, there will be significant implications for the UK's IP laws. The first, and perhaps most problematic for the UK, will be the loss of access to the specialized IP agencies and systems that form part of the EU's acquis. In the fields of trade mark and patent, IP policy has moved from the approximation of national laws so as to facilitate market integration (see for example European Commission, 1976, p. 7 for justifications for the creation of an EEC trademark; see also Kur, 1997; Dinwoodie, 2013) to the establishment of supranational regimes. In the 1990s, the then European Economic Community (EEC) established the Community Trade Mark, by way of Council Regulation 
No.40/94, allowing for a single registration at the Office for the Harmonization of the Internal Market (OHIM) resulting in automatic protection in the entire EEC upon approval of the application (for more on the Community Trade Mark, see Jehoram et al., 2010, p. 17). This system of registration has been codified and updated with the establishment of the EU Trade Mark by Regulation 2015/2424, which also renamed OHIM the European Union Intellectual Property Office (EUIPO). This 'unification of rights' (Dinwoodie, 2013, p. 87) was intended to ensure that impediments to trade through differences in legal rights in different Member States could be removed, ensuring that trade mark in the EU is not subject to issues of territoriality or jurisdiction. This creates a problem for the UK upon its withdrawal from the EU - the EU Trade Mark is only valid within the EU Member States. This means that British firms that have sought only a Community (or now EU) Trade Mark without also securing a national trade mark will be required to apply for a national trade mark to receive protection in the UK, unless the British Government provides for the automatic granting of a UK mark upon EU withdrawal; similarly, this could be problematic for non-UK based firms whose brands are protected by the EU Trade Mark, who may need to apply for a national mark in the UK. This is already the case for EEA states Norway, Iceland and Liechtenstein, which require both a national registration and subsequent EU Trade Mark registration, as EEA members are not within the jurisdiction of the EUIPO. UK-based firms in the future wishing to gain Europewide trade mark protection will have to apply both in the UK for a national mark and at EUIPO for an EU Mark, increasing the time and cost of application. A UK registration is currently a minimum $£ 170$ if performed online (Intellectual Property Office, 2016), with an EU registration costing a minimum of $€ 850$ (EUIPO, 2016). An additional benefit of the EU Trade Mark, according to Cook, is that it can ensure protection in Member States where a firm may not have a previously established reputation or consumer recognition, which may be important in determining whether a sign is distinctive enough to be given trade mark protection (2016); by adding an additional layer of complication to the application process, UK-based firms seeking to expand into European markets may find that brand distinctiveness and recognition in the UK may not be sufficient for EU protection. While assessment of the potential financial implications of this move is somewhat difficult to quantify at this juncture, a joint European Patent Office (EPO) and EUIPO report published in October 2016 indicates that the UK has filed 10,206 trade mark applications at the EU level as a 2011-2013 average, rating as the second most frequent filer of applications (EPO and EUIPO, 2016, p. 90). Furthermore, trade mark intensive industries constitute a 38.4 per cent share of UK GDP, with 
$€ 762,325$ million value added and representing 21.2 per cent of national employment (EPO and EUIPO, 2016, p. 82). The loss of access to the EU Trade Mark on its current terms will no doubt have financial as well as legal implications.

With regard to patents, a measure supported by the UK was the creation (by enhanced cooperation) of the EU 'unitary' patent and specialized court (Barnier, 2012), which would allow for the granting of a patent with automatic validity in the entirety of the EU, excluding Spain, which opted out of the regime (West et al., 2013, p. 105). This system would run alongside the existing national patent grants or 'bundle of patents' that could be sought by firms under the European Patent Convention through the EPO, an international organization outwith the EU system which the UK will remain party to subsequent to EU withdrawal (for more on the functioning of the patent, see Christou, 2013; see also Kaesling, 2013). The UK was instrumental in securing the patent, particularly in the Council of the European Union (Pagenberg, 2013), and perhaps more importantly, one of the central divisions of the Unified Patent Court (UPC) was to be situated in London, under Article 7 of the UPC Agreement. By leaving the EU, the existence of the EU's unitary patent is in doubt; as the regime is only open to membership of EU Member States, and not EEA members, the UK will not be able to participate, and legislation establishing the regime may need to be rewritten in light of the UK's withdrawal. It may be, however, that without the influence of the UK, impetus for the further integration of IP in the internal market is reduced, as well as serving to jeopardize existing integration measures. Tilman argues that the unitary patent project could nevertheless proceed by the UK ratifying the Agreement prior to exiting the EU, allowing for the UPC to become operative, and then entering into an agreement to continue membership of the system by means of a Protocol after it leaves (2016). However, Dunlop argues that this is highly unlikely - more likely is that if the EU wishes to continue with the UPC project, the Agreement will have to be revised to take into account the UK's withdrawal, and that the unitary patent system will be open for adoption by EU Member States only (2016). The result is likely to be highly uncertain; with the UK being fourth in the EU in terms of patent applications registered at the EPO (EPO and EUIPO, 2016, p. 90) and patent intensive industries representing 13.3 per cent of UK GDP and 8.3 per cent of employment (EPO and EUIPO, 2016, p. 81), this uncertainty is likely to impact upon British business. 
In the field of copyright, the most pressing issue for the EU at this time has been the facilitation in the cross-border sales of digital media, be it in the form of music or eBook downloads, or access to legal streaming services such as Netflix (European Commission, 2010b; European Commission, 2015a; Farrand, 2016a). Unlike trade mark, there is no supranational copyright system in the EU, only the approximation of national laws (Farrand, 2015; Hugenholtz, 2012). Therefore, copyright is still territorial in nature, and subject to enforcement in national jurisdictions. While the Court of Justice has sought to ensure that the exercise of IP rights cannot serve as a barrier to the free movement of physical goods since cases, the situation is more complicated when applied to digital media, which is instead classified as a service (Dreier, 2013), which can be subject to territorial restrictions in order to, for example, effectively calculate royalty payments (Mazziotti, 2010). Nevertheless, with the widespread usage of the Internet for the dissemination of copyright protected works, this territoriality has been recognized by the Commission as an undesirable barrier to trade (European Commission, 2010b) and that restricting access to digital media content by geographical location, so that content made available in the UK is only accessible in the UK, significantly hinders the establishment of a 'pan-European' market for digital media services (European Commission, 2015a, pp. 6-7). The UK has been a strong proponent of creating a single market for the sale and access of copyright protected digital media (HM Government, 2014, p. 35), as have representatives of the British creative industries, which believe that further integration of the (digital) single market would result in increased economic growth and a wider customer base (HM Government, 2014, pp. 80-81). In the event that the UK withdraws from the EU on the basis of an EEA relationship, then the UK is likely to retain access to this formative Digital Single Market. The Commission has indicated that the proposed legislation, including a Regulation ensuring the cross-border 'portability' of content, allowing for users to access content legally available in their home state when travelling to another Member State, has EEA relevance (European Commission, 2015b, p. 10), which means that members of the EEA will be required to adopt that legislation in order to be able to trade with the EU. However, in the event that the UK instead opts for bilateral relations with the EU similar to the Switzerland model, a customs union, or alternatively on the basis of operating under WTO rules only, the UK will lose access to the potentially lucrative single market for digital media services. UK-based consumers would not be able to access UK-based content when travelling in the EU, and EU-based consumer happening to be temporarily present in the UK would not be able to access EU-based content. While harder to calculate than trade mark 
or patent, as copyright is an unregistered right, it is nevertheless worth stating that copyright intensive industries contribute 8.4 per cent of UK GDP, with a value of $€ 167,683$ million and employing 6.3 per cent of the working population (EPO and EUIPO, 2016, p. 84).

Finally, withdrawing from the EU would have implications for enforcement of IP rights due not only to loss of access to the EUIPO, but loss of access to Europol, which only provides full membership for EU members (Larsson, 2006). While it may be argued that the main activity of the EUIPO is in its role as the agency responsible for the EU Trade Mark, the EUIPO is also home to the European Observatory on Infringements of Intellectual Property Rights, which is responsible for sharing best practices in identifying, monitoring and countering infringements of IP carried out on a commercial scale, such as counterfeiting (Farrand, 2017). The European Observatory's work in particular on centralizing information regarding identifying alleged counterfeiters operating on the Internet for the purposes of injunctions and initiation of legal action in the different Member States (European Observatory on Counterfeiting and Piracy, 2010, pp. 3-5) is based on exchanges of expertise between national agencies (European Commission, 2009, p. 6), expertise which, in the event of leaving the EU, the UK would no longer have access to. Furthermore, Europol has been collaborating with the European Observatory in identifying key counterfeit markets and countries of origin, again working with national authorities in order to develop training in countering commercial scale infringement. Information exchange between national agencies becomes essential, as 'the internet is the most significant enabler for the distribution of counterfeit goods, because of [...] its ability to operate across various jurisdictions, and its potential for presenting sophisticated replicas of official web shops' (European Observatory on Infringements of Intellectual Property Rights and Europol, 2015, p. 5), which may target consumers in one particular Member State, but be identified as a site selling counterfeits in another Member State. As many of these goods sold come from outside the EU, but are sent directly to the purchaser in small consignments, rather than the traditional means of bringing counterfeit goods into a country in order to sell in physical black markets (see for example Schneider and Maillefer, 2015), the identification and seizure of these consignments requires effective data exchange between national agencies. While countries such as Norway do have co-operation agreements with Europol despite not being EU Member States, as evidenced by the Agreement between the Kingdom of Norway and the European Police Office that entered into force in 2001, Article 2 specifically outlines the types of offence in which co-operation 
between the national and European agencies is permitted. Whereas piracy and counterfeiting are identified as areas of 'cybercrime' in the European Convention on Cybercrime, IP-related crimes are not included in Article 2 of the Agreement. Switzerland, the non-EEA country with the closest relationship with the EU also has a co-operation agreement, but again under Article 3, this does not apply to IP-related offences, meaning information exchange in these fields is somewhat unlikely. Losing access to these central repositories of expertise in the EUIPO and Europol may negatively impact the ability of the UK to effectively counter IP infringements. It may therefore be concluded that the impacts upon IP law and enforcement for the UK through withdrawal from the EU are both substantial and potentially serious.

\section{Boldly Independent, or Bound by Convention? The UK and IP Law Obligations}

Yet perhaps the loss of access to these agencies, as well as to these IP-focused markets, is a price worth paying for newly sought independence? When considering IP, it would seem that the UK is somewhat bound by convention. Let us start first with the 'softer' exit option, namely EEA membership. This type of relationship with the EU would require the UK to adopt certain Directives pertaining to IPRs, without the ability to influence their content. Under the EEA Agreement Article 65(2), EEA states are required to adhere to provisions on the protection of 'intellectual, industrial and commercial property, which, unless otherwise specified, shall apply to all products and services'. The list of laws requiring adoption is included in Annex XVII, which includes Directive 2009/24/EC on the protection of computer programs, Directive 2001/29/EC on the harmonization of certain aspects of copyright and related rights in the information society, Directive 2008/95/EC on the approximation of laws relating to trade marks, and Directive 98/44/EC on the legal protection of biotechnological inventions. This admittedly will have no immediate effect on the UK, which has already incorporated these laws into domestic legislation by virtue of its EU membership. As they have been incorporated into national law, they continue to constitute binding legal obligations 
until such time as the UK chooses to repeal them, a time-consuming and resource intensive task (Lazowski, 2016, pp. 124-125). This does have implications, however. The first is that the UK will have no flexibility under an EEA model to make significant reforms to its IP laws in fields subject to EU harmonizing measures; while there is no indication that the UK would want substantial change in this area, or at least that the area was not considered salient enough to be discussed in pro-Leave campaigning, it nevertheless suggests that IP would not be an area where the UK would be able to strip away burdensome 'red-tape' and achieve 'control of our own laws', as so desired by leading Brexit figures (Craig, 2016, p. 456). While the decisions of the ECJ would not directly bind the EU if an EEA member, it would nevertheless be subject to the scrutiny of the EFTA Court, which can issue advisory opinions under Protocol 35 of the EEA Agreement, which requires that in conflicts between the EEA Agreement and national law, the Agreement rules prevail (Burke et al., 2016, p. 80). Furthermore, the EFTA Court interacts with the ECJ through a process of judicial dialogue, deciding cases in line with ECJ decisions (Baudenbacher, 2004), and furthermore, has been shown to demonstrate a strong integrationist tendency that rivals that of the ECJ (Fredriksen, 2010a).

Furthermore, the UK would continue to be bound by new laws, without the ability to influence their content, indicating a loss of legal authority and influence, rather than a net gain (Lazowski, 2016, p. 120). As EU law changes so do the obligations of the EEA, which has to follow and adopt all future EU laws relevant for the internal market, particularly in areas of close integration (Tynes and Haugsdal, 2016, pp. 761-762). During the negotiations for the establishment of the EEA in the early 1990s, Cotter argued that being able to fully participate in decision-making and shaping was essential, commenting specifically with regard to IP that EEA states 'could come into a position of mere approval and reception of laws to whose 
creation they do not have any sufficient say' (1991, p. 149), a prediction largely born out in subsequent IP law and policy-making (see generally Fredriksen, 2010b; Rognstad, 2016). While it is true that the Commission wields the legislative agenda under the ordinary legislative procedure on matters concerning the internal market, including IP law under Article 118(1) TFEU, the UK has significant influence in the EU Council. Through a process of deliberative intergovernmentalism (Puetter, 2014, pp. 4-6), in which the ability to influence decision-making is 'dependent upon the ability to negotiate, compromise, build alliances/consensus and be a reliable partner' (Copsey, 2007, p. 14), the UK has wielded considerable influence, both being on the 'winning' side of negotiations 87 per cent of the time and UK officials being at the heart of EU bargaining, constituting the best connected officials in the Council (Hix, 2016, pp. 202-204). Through leaving the EU, the ability to shape IP laws that may nevertheless bind it will be severely curtailed.

In the event of choosing not to pursue the EEA option, but instead pursuing subject-specific bilateral agreements in the same way as Switzerland negotiates with the EU (Lavenex, 2009), facilitation of trade in IP protected materials such as digital media would require specific agreements to be concluded. Over the space of 40 years, the EU has concluded just 20 significant agreements with Switzerland on a range of subjects such as free movement of persons, civil aviation and education, as well as 100 minor agreements - these are however all negotiated sector by sector (Gstöhl, 2015) in a form of 'non-adhesive integration' with the EU legal order (Vallet, 2012, p. 377), also referred to as 'integration without membership' (Vahl and Gromilund, 2006). However, this process can be considered slow, laborious and technically complex (Burke et al., 2016; Lazowski, 2016). If the process of EU-UK negotiations is as slow, which could be the case given the complexity of negotiations and the limited trade expertise currently possessed by the country, the position of IP-intensive sectors based in the 
UK but trading in the EU may be one of an uncomfortable limbo. It is worth commenting here that the repercussions for the EU may not be so negative - the withdrawal of the UK may allow for further and deeper integration of areas of IP such as copyright law, as has been argued recently by some academics (see Sinodinou, 2016 for one example), which has been marked by a difference between 'Anglo-American' and 'Continental' approaches that prioritise differently the economic dimension and 'moral' dimension of copyright, which focuses on the rights of the author as a person rather than purely on the financial element. Such an argument must be made cautiously, however; this divergence in approach to copyright has been somewhat exaggerated (Strowel, 1994), and while the UK has been much more sceptical of deeper integration in fields such as Economic and Monetary Policy and social rights, it has been much more supportive of market integration including in the field of IP. By pursuing such an option, the UK may be able to facilitate trade in IP-protected works through regulatory convergence with EU IP standards. However, such an approach would again have implications for UK 'independence'. Swiss-EU relations are marked by a self-imposed limitation on sovereignty, with Switzerland harmonizing its commercial laws with the EU to facilitate trade. Internal laws pertaining to economic matters are scrutinized in order to ensure compatibility with EU law resulting in a process of Europeanization without institutionalization, in which EU law is transposed through autonomous adaptation (Linder, 2013, p. 191). The restriction of national autonomy this necessitates, however, combined with the reluctance of the Swiss population to engage in further bilateral negotiations (particularly in light of migration-related issues) (Linder, 2013, p. 199) may constitute a dark omen for the UK, where a British population leaning towards a 'hard' Brexit may find even this level of integration unacceptable - indeed, as was noted in 2015 by Joseph Weiler, it is 'the very idea of membership in a Union such as the EU which at the end of the day simply does not sit well' 
(Weiler, 2015, p. 2). Suggesting a form of co-ordination with the EU in which EU laws are adopted without any say in their drafting may not be politically acceptable.

What if the UK pursued a WTO or Free Trade Agreement approach? Ultimately, with regard to IP protection, the UK would still find its ability to decide its own laws constrained. At the international level, IP is protected by the Agreement on Trade Related Aspects of Intellectual Property Rights, or TRIPS, concluded as part of the Uruguay Round of GATT negotiations. Ratification of TRIPS is a pre-requisite for WTO membership, with the result that abidance by the TRIPS requirements is necessary for the UK's membership of the organization. Those proponents of a WTO-only relationship may find however that negotiations are required to redefine its legal relationship with the WTO, albeit that the UK is argued to already constitute a member of the WTO independent of its EU membership, with its own rights and obligations independent of the WTO in line with WTO jurisprudence (Bartels, 2016, pp. 4-7). However, the process of 'uncoupling' its membership from that of the EU may nevertheless be legally and politically complex (Ungphakorn, 2016). 'Mere' renegotiation of the schedules of the WTO is by no means a straightforward or speedy process (Williams, 2008), with former WTO official Peter Ungphakorn stating that British renegotiation is 'not impossible, but it won't be sorted out quickly' (Beattie, 2016). Internationally, then, the UK's position in the world trading order, and its status as party to the TRIPS Agreement are both indeterminate - while undoubtedly TRIPS-compliant as a nation, the UK may nevertheless find its grey legal status uncomfortable if it is determined that formal accession to the WTO and ratification of TRIPS as an individual state party is deemed necessary. In addition, the UK is also a member of the World Intellectual Property Organization (WIPO) and will remain subject to its treaties, such as the WIPO Copyright Treaty and WIPO Performances and Phonograms Treaty by means of national incorporation of the provisions by way of the Information Society Directive 
(2001/29/EC), although as ratification was performed by the EU under its exclusive competence in external trade issues under Article 218(3) TFEU, the UK will likely need to reexamine and potentially renegotiate the terms of international agreements should it wish to either withdraw from them, or ratify as an independent state, a laborious and complicated process (Koutrakos, 2015, p. 2). However, as the next section of this article will demonstrate, (re)negotiation of agreements with other states may pose something of a difficulty for the UK.

\section{Cast Adrift? Brexit and a Global Loss of Influence over IP Law and Norms}

What if the UK attempted to negotiate something akin to a Free Trade Agreement (FTA) with the EU with principles pertaining to IP? Under the Treaty of Lisbon, the EU's Common Commercial Policy (CCP) was expanded to include specific exclusive competence over commercial aspects of IP protection (Müller-Graff, 2008, p. 190), now covered by Article 207(1) TFEU. In the interest of achieving a uniform approach to trade liberalization, Member States have in effect transferred their competences to conclude trade agreements to the EU, meaning that they are unable to conclude bilateral or plurilateral agreements with third states unless specifically empowered to by the EU institutions. The EU wields not only formidable power in trade, but formidable power through trade (Meunier and Nicolaïdis, 2006), constitutive of a deep trade agenda aimed at ensuring that EU-based firms are able to reap substantial benefits from trade liberalization while protecting and facilitating its own policy objectives and preferences internally. As Araujo has put it, 'it is globalization on the EU's terms' (2016, p. 46). The EU has conducted a significant number of FTAs and Stability and Association Agreements (SAAs) that have trade dimensions with states and regions, including agreements in force such as with South Korea, Jordan and Lebanon as well as countries in the EU's neighbourhood such as Albania, Moldova, Montenegro and Kosovo. Should the UK 
attempt the negotiation of such an agreement with the EU, it may find that the EU's power through trade, representing a bloc of 27 states upon which the UK substantially depends economically, results in the negotiation being on the EU's terms.

A number of agreements have been concluded (but only provisionally applied pending successful ratification of all parties) with countries such as Colombia, Peru and the Ukraine, as well as agreements with regions such as the Central American trade agreement with six Central American states, and the Caribbean Forum Economic Partnership Agreement. Furthermore, the EU is currently negotiating or concluding trade agreements with the US (the Transatlantic Trade and Investment Partnership), although its status is debatable given the election of Donald Trump, Canada (the Comprehensive Economic and Trade Agreement), which now appears to be ready for ratification, Japan, and African regions such as the Eastern African Community. While agreements such as those concluded with Colombia, Peru and the Caribbean Forum undoubtedly provide some benefits for those nations, the main benefit is for the IP-intensive sectors in the EU, which gain protections and rules for enforcement that go far beyond the standards provided for in the TRIPS Agreement (see generally Maskus, 2013). This is particularly the case for developing sectors such as the protection of geographical indications of origin, a sui generic form of protection for agricultural products deemed to possess intrinsic qualities, such as feta cheese, prosciutto di parma or Portuguese linguíça (on GIs see Blakeney, 2014; Calboli, 2015), identified as a key 'offensive' interest in trade agreements by the European Commission (Farrand, 2016b). GI protected foodstuffs are of considerable financial value to the EU and its agricultural producers, worth $€ 15.8$ billion in 2012 with an increase in sale value between 2005 and 2010 of 19 per cent (Chever et al., 2012, p. 16). The EU has adopted a position of exporting its norms for the protection of GIs by way of trade agreements, ensuring the protection of EU-produced products such as Feta in 
third countries, ensuring that only those cheeses produced within the EU subject to the requirements of the GI regime can use the name Feta. For example, the EU-South Korea Free Trade Agreement contains in Annex 10.A a list of products that must be afforded GI protection in South Korea, which includes products such as French cheeses, Italian cured meats and Czech beers. While there are no specific British products listed, what is apparent is the reciprocal nature of GI protection, with an agreement that certain EU-based GIs will be respected in South Korea, and vice versa. Furthermore, the strength of the EU in exporting its norms on IP protection throughout the world have been on the basis of its collective bargaining power as an economically dominant regional bloc able to offer 'sweeteners' to (often, but not always) developing countries as a means of ensuring compliance with EU IP laws (see for example Jaeger, 2013, pp. 203-204). It is debatable whether the UK acting as a single state without the collective power of the EU would have the same capacity to influence IP norms.

The UK is unlikely to be able to match this ability to export IP norms by way of trade agreements subsequent to leaving the EU. This is for two key reasons; the first is an issue of expertise, and the second an issue of importance. On the topic of expertise, with the negotiation of trade agreements constituting an exclusive EU competence, the UK has had less need to employ trade negotiators at the Foreign Office, and as a result, needs to hire a large number of staff to fulfil this role (Rutter and White, 2016). The UK currently has a civil service that is, according to one source, under-staffed, demoralized, and lacking in trade-related expertise (Barnard, 2016, p. 485). The government has estimated that it will need to employ approximately 700-750 negotiators, both for its complex and time-critical deliberations with the EU, as well as to begin to establish trade agreements with extra-communitarian states (Parker et al., 2016). This comparative lack of expertise puts the UK at a significant 
disadvantage when negotiating the terms of its withdrawal from the EU, which would presumably also include provisions concerning the protection of IP, particularly as it relates to the free movement of goods and services. However, given the likelihood that the UK will have more pressing issues to discuss with the EU, such as the conditions for market access, the (unlikely) compromises on the free movement of people while retaining access to markets for goods, services and capital and the passporting of UK-based financial firms, IP law is unlikely to be considered high priority to negotiators. It also has significant implications for the UK's negotiation of agreements with other states. As discussed above, international agreements the UK is party to by way of its membership of the EU will cease to apply for the UK subsequent to its withdrawal. Should CETA be ratified and enter into force, for example, the UK will no longer be a party to it; the same applies equally to the existing EU agreement with South Korea. In order to benefit from the same IP protections it currently enjoys under these agreements, the UK will have to renegotiate with those states. The difficulty for the UK is its lack of trade expertise at this point in time, compounded by the reality that while it may represent an attractive market, it does not have the same trade attractiveness (and indeed negotiating power) as a large trade bloc such as the EU (Lazowski, 2016). Indeed, at the time of writing, a number of states, including Australia, Brazil, Canada and India, have indicated that they have no immediate plans to enter into negotiations for trade agreements with the UK, and certainly not before its relationship with the EU is clarified (see for example Giles, 2016; The Economist, 2016).

\section{Concluding Thoughts}

If this article appears somewhat negative in its assessment of the potential impacts upon the $\mathrm{UK}$ as a result of the decision to leave the EU, it is due to the unfortunate conclusion that this 
withdrawal harms the UK more than it does the EU. While the UK has served as a driver of further integration of IP laws in the EU due to its support of its market goals (that have not necessarily translated into other policy areas), the potential loss of impetus for integration is a setback for the EU that pales in comparison to the loss of influence and protection that the UK may suffer as a result of this decision. In an era of increased global trade competition, one of the biggest strengths of the EU in its norm exportation and securing of regional interests has been the ability to act collectively as part of an economic bloc, a strength that the UK independently does not share. Furthermore, if the UK wishes to secure access to the internal market, it may nevertheless be bound by IP laws it has little ability to shape. Finally, with withdrawal from the EU comes loss of access to systems of protection such as the EU Trade Mark, a loss of access to agencies sharing expertise and enforcement information such as the EUIPO and Europol, and the creation of legal uncertainties regarding its ability to access the digital single market. Furthermore, the UK will find that its sovereignty post-Brexit is not as evident as it may believe as it pertains to IPRs, with a number of existing legal obligations, including under the TRIPS Agreement, which the UK is required to comply with, unless it seeks to also leave the WTO. With the need to renegotiate certain other international agreements the EU is already part of, but without the force of a 28 state bloc behind it, UK based IP-intensive firms may find that they face a period of significant uncertainty with regard to how, if at all, key sectors will be protected post-Brexit. While it may be bold, the UK may find that its position with regard to IPRs is not so independent; instead, it runs the risk of being politically isolated, and legally cut adrift.

\section{Correspondence:}

Benjamin Farrand

University of Warwick

Coventry 
CV4 7AL

Email: b.farrand@warwick.ac.uk

\section{References}

Araujo, B. A. M. (2016) The EU Deep Trade Agenda: Law and Policy (Oxford: OUP).

Barnard, C. (2016) 'The Practicalities of Leaving the EU'. European Law Review, Vol. 41, No. 1, pp. 484-486.

Barnier, M. (2012) 'Commissioner Barnier Welcomes Historic Agreement on the European Unitary Patent Package’ (Brussels).

Bartels, L. (2016) 'The UK's Status in the WTO after Brexit', SSRN Scholarly Paper (Rochester, NY: Social Science Research Network).

Baudenbacher, C. (2004) 'The Implementation of Decisions of the ECJ and of the EFTA Court in Member States' Domestic Legal Orders'. Texas International Law Journal, Vol. 40, p. 383.

Beattie, A. (2016) 'Brexit: Britain’s WTO Challenge Looms', Financial Times , 12 July.

Black, J. (2002) 'Mapping the Contours of Contemporary Financial Services Regulation'. Journal of Corporate Law Studies, Vol. 2, No. 2, pp. 253-287.

Blakeney, M. (2014) 'Geographical Indications: What Do They Indicate?' WIPO Journal, Vol. 6, No. 1, pp. 50-56.

Burke, C., Hannesson, O. and Bangsund, K. (2016) 'Life on the Edge: EFTA and the EEA as a Future for the UK in Europe'. European Public Law, Vol. 22, No. 1, pp. 69-96.

Calboli, I. (2015) 'Geographical Indications of Origin at the Crossroads of Local Development, Consumer Protection and Marketing Strategies'. International Review of Intellectual Property and Competition Law, Vol. 46, No. 7, pp. 760-780.

Chever, T., Renault, C., Renault, S. and Romieu, V. (2012) 'Value of Production of Agricultural Products and Foodstuffs, Wines, Aromatised Wines and Spirits Protected by a Geographical Indication' (Brussels: European Commission).

Christou, G. (2013) 'The Cyprus Presidency of the EU: "Real Achievements" in a "Filoxenos Topos"'.JCMS, Vol. 51, pp. 80-88.

Cook, T. (2016) 'The Differing Protective Scope of Registered Trade Marks in Europe'. Journal of Intellectual Property Rights, Vol. 21, pp. 180-183.

Copsey, N. (2007) 'The Member States and the European Neighourhood Policy' (European Research Institute: University of Birmingham). 
Cotter, T. F. (1991) 'Perspectives of Intellectual Property Law in the Triangle of GATT, the European Community and a European Economic Area'. Entertainment Law Review, Vol. 2, No. 5, pp. 147-150.

Craig, P. (2016) 'Brexit: A Drama in Six Acts'. European Law Review, Vol. 41, No. 4, pp. 447468.

Dinwoodie, G. (2013) 'The Europeanization of Trade Mark Law'. In Pila, J. and Ohly, A. (eds.) The Europeanization of Intellectual Property Law: Towards a European Legal Methodology (Oxford: Oxford University Press).

Dreier, T. (2013) 'Online and Its Effect on the "Goods” Versus "Services" Distinction'. IIC International Review of Intellectual Property and Competition Law, Vol. 44, No. 2, pp. 137-139.

Dunlop, H. (2016) 'What Now for the Unified Patents Court Following the Brexit Referendum?' European Intellectual Property Review, Vol. 38, No. 10, pp. 595-597.

EPO and EUIPO (2016) 'Intellectual Property Rights Intensive Industries and Economic Performance in the European Union' (Alicante: European Union Intellectual Property Office).

EUIPO (2016) Fees and Payments (Alicante: European Union Intellectual Property Office). Available online at: https://euipo.europa.eu/ohimportal/en/fees-and-payments.

European Commission (1976) 'Memorandum on the Creation of an EEC Trade Mark', SEC(76) 2462, July 1976

European Commission (2009) 'Enhancing the Enforcement of Intellectual Property Rights in the Internal Market', COM(2009) 467, 11/09/2009.

European Commission (2010a) 'Europe 2020: A Strategy for Smart, Sustainable and Inclusive Growth', COM(2010) 2020, 03/03/2010.

European Commission (2010b) 'A Digital Agenda for Europe', COM(2010) 245, 19/05/2010.

European Commission (2011a) 'A Single Market for Intellectual Property Rights: - Boosting Creativity and Innovation to Provide Economic Growth, High Quality Jobs and First Class Products and Services in Europe', COM(2011) 287, 24/05/2011.

European Commission (2011b) 'Single Market Act: Twelve Levers to Boost Growth and Strengthen Confidence "Working Together to Create New Growth"', COM(2011) 206, 13/04/2011.

European Commission (2015a) 'A Digital Single Market Strategy for Europe', COM(2015) 192, $06 / 05 / 2015$.

European Commission (2015b) 'Proposal for a Regulation on Ensuring the Cross-Border Portability of Online Content Services in the Internal Market', $\operatorname{COM(2015)~627,~}$ $09 / 12 / 2015$. 
European Observatory on Counterfeiting and Piracy (2010) 'Evidence and Right of Information in Intellectual Property Rights', (Alicante: European Union Intellectual Property Office.

European Observatory on Infringements of Intellectual Property Rights and Europol (2015) 2015 Situation Report on Counterfeiting in the European Union (Alicante: European Union Intellectual Property Office).

European Patent Office and European Union Intellectual Property Office (2013) 'Intellectual Property Rights Intensive Industries: Contribution to Economic Performance and Employment in the European Union', Industry-Level Analysis Report (Alicante: European Union Intellectual Property Office).

Farrand, B. (2015) 'Lobbying and Lawmaking in the European Union: The Development of Copyright Law and the Rejection of the Anti-Counterfeiting Trade Agreement'. Oxford Journal of Legal Studies, Vol. 35, No. 3, pp. 487-514.

Farrand, B. (2016a) 'The EU Portability Regulation: One Small Step for Cross-Border Access, One Giant Leap for Commission Copyright Policy?' European Intellectual Property Review, Vol. 38, No. 6, pp. 321-325.

Farrand, B. (2016b) 'Two Continents, Divided by Deep Philosophical Waters?' European Journal of Risk Regulation, Vol. 7, No. 2, pp. 269-273.

Farrand, B. (2017) 'Combatting Physical Threats Posed via Digital Means: The European Commission's Developing Approach to the Sale of Counterfeit Goods on the Internet'. European Politics and Society, (forthcoming).

Fredriksen, H. H. (2010a) 'The EFTA Court 15 Years On'. International \& Comparative Law Quarterly, Vol. 59, No. 3, pp. 731-760.

Fredriksen, H. H. (2010b) 'One Market, Two Courts: Legal Pluralism vs. Homogeneity in the European Economic Area'. Nordic Journal of International Law, Vol. 79, No. 4, pp. 481499.

Giles, C. (2016) 'UK Trade Deal far from Top Priority for Canada', Financial Times, 21/11/2016. Available online at: https://www.ft.com/content/47c59030-ac11-11e6-9cb3bb8207902122.

Gstöhl, S. (2015) 'Models of External Differentiation in the EU's Neighbourhood: An Expanding Economic Community?' Journal of European Public Policy, Vol. 22, No. 6, pp. 854-870.

Hall, B. H. (2009) 'Business and Financial Method Patents, Innovation, and Policy'. Scottish Journal of Political Economy, Vol. 56, No. 4, pp. 443-473.

Hix, S. (2016) 'Does the UK Have Influence in the EU Legislative Process?' The Political Quarterly, Vol. 87, No. 2, pp. 200-208.

HM Government (2014) 'Review of the Balance of Competences between the United Kingdom and the European Union; The Single Market: Free Movement of Services' (London: HMSO). 
Hugenholtz, P. B. (2012) 'Harmonisation or Unification of European Union Copyright Law'. Monash University Law Review, Vol. 38, No. 1, p. 4.

Intellectual Property Office (2015) Fast Facts (London: Intellectual Property Office).

Intellectual Property Office (2016) Trade Mark Forms and Fees (London: Intellectual Property Office). Available online at: https://www.gov.uk/government/publications/trademark-forms-and-fees/trade-mark-forms-and-fees.

Jaeger, T. (2013) 'IP Enforcement Provisions in EU Economic Partnership Agreements'. In Drexl, J., Khan, H. G. R. and Nadde-Phlix, S. (eds.) EU Bilateral Trade Agreements and Intellectual Property: For Better or Worse? (New York: Springer).

Jehoram, T. C., Nispen, C. van and Huydecoper, T. (2010) European Trademark Law: Community Trademark Law and Harmonized National Trademark Law (Alphen aan den Rijn: Kluwer Law International).

Kaesling, K. (2013) 'The European Patent with Unitary Effect - a Unitary Patent Protection for a Unitary Market?' UCL Journal of Law and Jurisprudence, Vol. 2, No. 1, pp. 87-111.

Koutrakos, P. (2015) 'Brexit and International Treaty-Making'. European Law Review, Vol. 41, No. 1, pp.1-3.

Kur, A. (1997) 'Harmonization of the Trademark Laws in Europe: An Overview'. International Review of Intellectual Property and Competition Law, Vol. 28, No. 1, pp. 1-23.

Larsson, P. (2006) 'International Police Co-operation: A Norwegian Perspective'. Journal of Financial Crime, Vol. 13, No. 4, pp. 456-466.

Lavenex, S. (2009) 'Switzerland's Flexible Integration in the EU: A Conceptual Framework'. Swiss Political Science Review, Vol. 15, No. 4, pp. 547-575.

Lazowski, A. (2016) 'EU Withdrawal: Good Business for British Business?' European Public Law, Vol. 22, No. 1, pp. 115-129.

Linder, W. (2013) 'Switzerland and the EU: The Puzzling Effects of Europeanisation without Institutionalisation'. Contemporary Politics, Vol. 19, No. 2, pp. 190-202.

Maskus, K. E. (2013) 'Assessing the Development Promise of IP Provisions in EU Economic Partnership Agreements'. In Drexl, J., Khan, H. G. R., and Nadde-Phlix, S. (eds.) EU Bilateral Trade Agreements and Intellectual Property: For Better or Worse? (New York: Springer).

Mazziotti, G. (2010) 'New Licensing Models for Online Music Services in the European Union: From Collective to Customized Management'. Columbia Journal of Law \& the Arts, Vol. 34, p. 757.

McCreevy, C. (2006) 'The New Global Regulatory Agenda in Financial Services: A Framework for the Twenty-First Century'. International Finance, Vol. 9, No. 3, pp. 381-392. 
Meunier, S. and Nicolaïdis, K. (2006) 'The European Union as a Conflicted Trade Power'. Journal of European Public Policy, Vol. 13, No. 6, pp. 906-925.

Müller-Graff, P. -C. (2008) 'The Common Commercial Policy Enhanced by the Reform Treaty of Lisbon?' In Dashwood, A. and Maresceau, M. (eds.) Law and Practice of EU External Relations: Salient Features of a Changing Landscape (Cambridge: CUP), p. 188.

Pagenberg, J. (2013) 'Unitary Patent and Unified Court - What Lies Ahead?' Journal of Intellectual Property Law \& Practice, Vol. 8, No. 6, pp. 480-485.

Parker, G., Gordon, S. and Neville, S. (2016) 'Britain Turns to Private Sector for Complex Brexit Talks', Financial Times, 5 July.

Patterson, L. R. (1986) 'A Regulatory Theory of Copyright: Avoiding a First Amendment Conflict'. Emory Law Journal, Vol. 35, p. 163.

Posner, R. A. (2005) 'Intellectual Property: The Law and Economics Approach'. Journal of Economic Perspectives, Vol. 19, No. 2, pp. 57-73.

Puetter, U. (2014) The European Council and the Council: New Intergovernmentalism and Institutional Change (Oxford: OUP).

Rognstad, O.-A. (2016) 'Intellectual Property Law'. In Baudenbacher, C. (ed.) The Handbook of EEA Law (Berlin: Springer), pp. 703-720.

Rutter, J. and White, H. (2016) Planning Brexit: Silence Is Not a Strategy (London: Institute for Government).

Schneider, M. and Maillefer, C. (2015) 'How Europe Deals with Private Imports of Counterfeit and Pirated Goods'. Journal of Intellectual Property Law \& Practice, Vol. 10, No. 4, pp. 262-268.

Sinodinou, T. (2016) 'Brexit and European Copyright Law: Some Conclusions and Delusions', Kluwer Copyright Blog Available online at: http://kluwercopyrightblog.com/2016/06/30/brexit-and-european-copyright-lawsome-conclusions-and-delusions-2/.

Strowel, A. (1994) 'Droit D'auteur and Copyright: Between History and Nature'. In Sherman, B. and Strowel, A. (eds.) Of Authors and Origins: Essays on Copyright Law (Oxford; New York: Clarendon Press; Oxford University Press).

The Economist (2016) 'India and Britain: A Cooler Climate', 10 November.

Tilmann, W. (2016) The Future of the UPC after Brexit Hogan Lovells Available online at http://www.theunitarypatent.com/the-unitary-patent-regulation-and-upc-agreementafter-brexit.

Tynes, D. S. and Haugsdal, E. L. (2016) 'In, out or in-between? The UK as a Contracting Party to the Agreement on the European Economic Area'. European Law Review, Vol. 41, No. 5, pp. 753-765. 
Ungphakorn, P. (2016) Nothing Simple about UK Regaining WTO Status Post-Brexit International Centre for Trade and Sustainable Development Available online at: http://www.ictsd.org/opinion/nothing-simple-about-uk-regaining-wto-status-postbrexit.

Vahl, M. and Gromilund, N. (2006) 'Integration Without Membership: Switzerland's Bilateral Agreements with the European Union' (Brussels: Centre for European Policy Studies).

Vallet, G. (2012) 'Should I Stay or Should I Go? Switzerland and the European Economic and Monetary Integration Process'. Journal of Economic Integration, Vol. 27, No. 3, pp. 366385.

Weiler, J. (2015) 'Brexit: No Happy Endings'. European Journal of International Law, Vol. 26, No. 1, pp. 1-7.

West, A., Kusumakar, S. and Powell, T. (2013) 'Unitary Patents and the Unified Patent Court'. Computer and Telecommunications Law Review, Vol. 19, No. 4, pp. 105-107.

Williams, P. J. (2008) A Handbook on Accession to the WTO: A WTO Secretariat Publication (Cambridge: Cambridge University Press). 